\title{
ХАРАКТЕРНИЦТВО ЯК УКРАЇНСЬКИЙ НАЦІОНАЛЬНИЙ ФЕНОМЕН (НА МАТЕРІАЛІ РОМАНУ Ю. МУШКЕТИКА ПОГОНЯ)
}

\section{ЛЮДМИЛА РОМАС}

Дніпропетровський національний університет імені Олеся Гончара, Дніпропетровськ - Україна

\section{KOZACKI CHARAKTER JAKO UKRAIŃSKI FENOMEN NARODOWY (NA PODSTAWIE POWIEŚCI J. MUSZKETYKA POGOŃ)}

\section{LUDMIŁA ROMAS}

Dniepropietrowski Uniwersytet Narodowy im. Olesia Honczara, Dniepropietrowsk - Ukraina

STRESZCZENIE. Artykuł poświęcony został artystycznej realizacji fenomenu charakteru kozackiego w powieści Jurija Muszketyka Pogoń. Typologiczne zestawienie postaci kozaka w powieści Muszketyka zostało ukazane na tle innych utworów literackich.

\author{
THE COSSACK CHARACTER AS A UKRAINIAN NATIONAL \\ PHENOMENON \\ (BASED ON THE NOVEL POGONYA - THE CHASE - BY YU. MUSHKETYK)

\section{LUDMILA ROMAS} \\ Oles Honchar Dnipropetrovsk National University, Dnipropetrovsk - Ukraine
}

ABSTRACT. The article is devoted to investigating the artistic embodiment of the Cossack character phenomenon in the novel Pogonya by Mushketyk. The typological comparison of the Cossack character image in the novel by Mushketyk is shown on the basis of other literary works.

$\mathrm{B}$ осмисленні особливостей національного самоусвідомлення найбільш сутнісні функції, безумовно, належать типу характерника. Останній постає не стільки як той чи інший різновид психологічної сутності людини, скільки як усталений і сформований духовний світ особистості, що не підлягав впливу з боку середовища людей, навпаки, поставав як самодостатній феномен, утворений специфічним побутуванням. До такого типу віднести можна зокрема козацтво. Д. Яворницький, котрий уперше звернувся до формування цілісної історії українського козацтва, використовував поняття $x a$ рактерник як цілком усталену назву, виплекану на основі народної уяви про мораль, коли за цим словом стояв певний колективний стереотип, широко знаний на теренах України. Найголовніша дефініція характерництва безпосередньо пов'язувалася з магією й умінням чарувати: 
[...] так звані характерники, котрих ні огонь, ні вода, ні шабля, ні звичайна куля, крім срібної, не брали. Такі характерники могли відмикати замки без ключів, плавати човном по підлозі, як по морських хвилях, переправлятися через ріки на повстині і рогожі, брати голими руками розпечені ядра, бачити на кілька верстів навколо себе за допомогою особливих верцзадел, жити на дні ріки, залазити й вилазити з міцно зав'язаних чи навіть зашитих мішків, „перекидатися” на котів, перетворювати людей на кущі, вершників на птахів, залазити у звичайне відро й пливти в ньому під водою сотні й тисячі верстів ${ }^{1}$.

У той же час внутрішня природа буття характерника визначалася, за Д. Яворницьким, ще й свідомою настановою на філософськи пояснювані моменти: „Тут було своєрідне молодецтво і особливий, епікурейський погляд на життя людини, котра даремно обтяжує себе працею і турботами, не розуміючи справжнього сенсу життя - існувати для веселощів і радості”, хоча, додає дослідник, „,...] в основі характеру козака, як і кожної руської людини, завжди зауважувалася якась двоїстість"2.

Відштовхуючись від досить сталих уявлень про подібний внутрішній устрій знаного на чарах козака, Юрій Мушкетик у художньому осмисленні образу характерника виходить зовсім з інших позицій, що, на наш погляд, пояснюється насамперед специфікою історичного часу Руїни, який складає основне авторське зацікавлення. М. Грушевський відзначав: „На початку XVII в. [...] політична і соціальна структура Східньої України (Гетьманщини) значно ствердла $[. .$.$] коштом приборкання і апатії народніх мас"3. Тому голов-$ ний герой роману Погоня (1997) Семен Білокобилка, виведений автором як характерник, перебирає на себе основні функції народного характеру як такого. Легкий натяк на двоїстість натури планетника в контексті твору перетворюється на головний внутрішній конфлікт козака, котрий поєднує в собі одночасно й риси мужнього звитяжця, і природжений потяг до щастя, яке можливе лише в родинній і мирній праці, і філософське начало національної свідомості.

Роздуми Юрія Мушкетика стосовно трагічної сутності історичного розвитку України за часів поступового відмирання інституту козацтва символічно втілюються вже в самій назві твору. Погоня, в якій непередбачувано міняються місцями втеча і лови, як і ті, хто беруть у них участь, у найзагальнішому розумінні символізує людське життя, що розгортається як одвічна погоня за примарним щастям, одвічна втеча людини від самої себе й одвічний пошук власного місця під сонцем. 3 другого боку, чи не найточніше передає образ погоні тривожний дух останніх років існування козацької вольниці, коли Україна постає як спіймана і розшматована хижими сусідами лебідка.

${ }^{1}$ Д. Я в о р н и ц ь к и й, Історія запорозьких козаків, т. І, Київ 1990, с. 560.

${ }^{2}$ Там само с. 180.

${ }^{3}$ М. Г р у ш е в с ь к и й, Виговський $і$ Mазеnа, [в:] Ю. М у ш к е т и к, На брата брат, Київ 1993, с. 318. 
У Ю. Мушкетика сам принцип організації сюжету як мерехтливого чергування втечі-погоні передбачає вихід на фрагментарні чергування різних сцен 3 життя українського села і козацтва, що лише поступово вкладаються в певну цілісну картину розтерзаної, конаючої України. Іншим аспектом двоїстої природи художнього викладу постає той факт, що оповідь то ведеться від першої особи (самим Семеном Білокобилкою), то знову повертається до об'єктивізованого викладу подій автором. Такий прийом дозволяє Юрію Мушкетику весь час тримати героя на своєрідній межі між буттям звичайної людини і характерництвом.

У романі фактично відображена історична ситуація, коли зміна військової демократії, розшарування козацтва, ліквідація гетьманату, історичне роз'єднання українських земель, що перебували у складі Росії та Польщі, спричинили катастрофічний злам народної свідомості, відродження можливе лише за умови зміни соціального і духовного ідеалу: від батька гетьмана до батька родини, яке, проте, так і не реалізується в життя.

На відміну від Козака Мамая О. Ільченка в романі Козацькому роду нема переводу, або ж Мамай $і$ Чужа Молодиия (1958) (символічному образу, цілком витриманому в контексті характеристик, визначених Д. Яворницьким), Семен Білокобилка в Юрія Мушкетика максимально наближений до реалій життя, усіма прагненнями своїми звернений до рідного села, неньки, коханої. Мушкетиківський герой у критичних ситуаціях здатний не просто вагатися, а навіть втрачати надію і віру в себе, як в епізоді з несправедливим звинуваченням у вбивстві селянина, коли його приковують до труни забитого, щоб живцем поховати разом з покійником, тільки церковна миша надихає його поборотися не стільки за своє життя, скільки за життя залишених у смертельній загрозі товаришів. Ільченківський Мамай - це невмирака-невмирайло, якого

$[\ldots]$ самісінькі стонадцять кіп чортів [...] носили по всій Україні - протягом незліченної рахуби років, оті сто копанок чортів, котрі носять по нашій вільній землі і тепер, і сьогодні, зараз, котрі носитимуть його між нами й завжди [...], поки живі є ми, поки існує на світі славний український народ ${ }^{4}$.

Химерність у О.Ільченка - це в першу чергу стан свідомості, який і зумовив необхідність повернення до тотемних образів, коли людина та іï̈ зооморфний предок існували як єдине ціле. Художнє обгрунтування особливостей сучасного міфомагічного мислення підпорядковане закономірностям архаїки в усій їі багатогранності, чітко означеним відомим міфологом В. Іорданським, який акцентував на тому, що

[...] природна в архаїчній свідомості тенденція до олюднення міфічних сил разом з тим - далеко не єдина і навіть не головна, оскільки міфічні сили за своєю природою

${ }^{4}$ О. І л ь ч е н к о, Козаиькому роду нема переводу, або ж Мамай $і$ Чужа Молодиия, Київ 1967, с. 537. 
належать до середовища. яке за багатьма ознаками протилежне власне людському, наділяючи їх, таким чином, і рисами, протилежними власне людському ${ }^{5}$,

що й притаманне поетиці роману О. Ільченка.

В. Нарівська зазначає:

Козак Мамай О.Ільченка, як і будь-який герой міфу (а він дійсно є героєм не фольклору, а народної міфології), амбівалентний і несе в собі риси абрека, тобто героя-одинака, який нехтує законами божими, людськими в ім'я святих ідеалів національної свободи, захисту релігії і соціальної справедливості. На цих засадах була побудована Січ. Козак Мамай $€$ носієм ії ідеалів, яким би неоднозначним він не був ${ }^{6}$.

Порівняльний аспект типу козака-характерника є предметом іншої роботи, тому в цій статті увага зосереджена на особливостях творення такого образу тільки в романі Ю. Мушкетика, де його внутрішня наповненість досить амбівалентна. Семен весь час прагне перейти до самостійного вивершення свого життєвого кола, відверто зізнається, що хотів би подбати про себе, і в той же час усі несправедливості, усе горе людей входять у його серце: „Я не хочу ні за кого бути в одвіті, але хіба можна прожити життя в одвіті тільки за себе самого?"”. Ось чому шалений скач 3 одного берега України на інший для порятунку товаришів на останній межі сил гонить Семена через увесь роман. А в серці героя $є$ чітке усвідомлення як власної сили, так і ії̈ безкінечної змалілості перед найвищою миттю людського щастя. Остання - це

[...] мить 3 запахом вишневого клею і смородинового листя, 3 пронизливим щемом минущості та вічності, саме та, 3 юності, вирвана, подарована вищими силами, 3 якими я не завжди в злагоді, пролітала крізь серце, неначе стріла. Я багато валасався світом, багато чого знаю та вмію, навіть такого, чого не вміє ніхто, я можу стиснути думку, й не тільки свою, можу брати людей у свою волю, сього навчився в одного січового діда й трохи од турків та татар, але тих митей народжувати не вмію ${ }^{8}$

Опосередковане вказування на появу незвичайних здібностей, які з'явилися в Семена під впливом старого січовика, турків і татар, посилюється неодмінною атрибутикою характерника - сережкою у вусі. Та ії придбання пов'язане знову ж таки з цілком реальним проходженням через переживання смерті, яка забрала всіх, а Білокобилку після бубонної чуми залишила жити. Сережка

[...] дісталася мені від галерника Корсака, - передав перед смертю, не золота, не срібна, але блискуча, сяйна, на ній якісь таємничі знаки - півмісяці, ніколи й ніде не бачені звізди, турки хотіли забрати її в Корсака, а тоді чомусь жахнулися й більше не

${ }^{5}$ В. И о р д а н с к и й, Звери, люди, боги, [в:] Очерки африканской мифологии, Москва 1991, c. 319.

${ }^{6}$ В. Н а р і в с ь к а, Національний характер в украӥнській прозі 50-70 років XX століття, Дніпропетровськ 1994, с.204.

${ }^{7}$ Ю. М у ш к е т и к, Погоня. Прийдімо, вклонімось, [в:] його ж, Романи, Київ 1997, c. 440 .

${ }^{8}$ Там само, с. $102-103$. 
чіпали, і козаки її не люблять, не люблять навіть дивитися на неї, а мені вона до душі, й не просто до душі, коли наляже на серце туга, або коли потраплю в скруту, помацаю сережку і туга відлітає, й прибуває сили․

Мушкетик, майже переконавши в цілковитій приналежності Семена до характерництва, увесь час залишає хисткий місток. На межі хворобливого стану і реальності відбувається розмова козака з чортом на болоті, у такому ж стані напівмарення Білокобилка чи то перепливає, чи то перелітає Дніпро. У снах він звершує свої польоти, що з часом стають усе нижчими та нижчими. Його буття в романі розгортається як постійне випробування на життєздатність, і кожна перемога над небезпекою і смертю робить Семена сильнішим, та в час найбільшої напруги товариш Пукавка говорить Білокобилці:

Ти бадьоришся. А сам - такий, як ми. І шкура на тобі така сама, і дірки в ній проштрикують так само, і серце таке. I гріш рахуєш, як ми. Може, трошки дужчий, - одчайдуха - та затятіший, але й добріший ${ }^{10}$.

3 одного боку, функція ката, безумовно, наявна у внутрішній характеристиці Семена Білокобилки, але викликана вона особистою образою і пекельним болем, з яким живе він у світі. Пана Юса намагається наздогнати і скарати, щоб помститися за кривду коханої Мальви, Пиво знаходить свою смерть від руки месника за сплюндрування і призведення до загибелі найсвятішого, що колись було в житті героя, - його сестри Василини. Але інша іпостась Білокобилки вимальовується, коли він рятує від вірної смерті селянина Кирика, якого заплітають головою в живопліт, чи коли кладе на сирітські та вдовині призьби мішки 3 житом та пшеницею, і місто повниться чутками про невидимого святого. Глибоко заховувана навіть від самого себе чутливість і вразливість душі Семена найповніше розкривається в його почутті до Мальви. Слово кохана, що піднімається десь аж зі споду душі, наповнює його сонячною радістю і відчуттям щастя.

Мерехтлива природа характерництва героя по-різному виявляється і в його зовнішньому вигляді. Коли доводиться рятувати від спалення його майбутню кохану, Семен змінюється, „[...] в його обличчі проступило щось хиже, очі горіли жаско, простерта лівиця тремтіла” ${ }^{\prime 1}$; „Білокобилка бликнув 3-під гострих брів. Його обличчя було неначе викуване з бронзи, ніс закінчився, очі горіли синім вогнем"12. Така портретна проявленість характерництва як начала, пов'язаного з інфернальністю, різко контрастує зі згрубіло-зніяковілою самохарактеристикою героя, яку він складає при спілкуванні з Мальвою:

I я подумав, що хоч трохи вкинув іiї в хвилювання, що таки не зовсім старий та бридкий і ще можу хвилювати жінок. Це знав і раніше. Обличчя в мене, може, й сокирою

\footnotetext{
${ }^{9}$ Там само, с. 36 .

${ }^{10}$ Там само, с. 440.

${ }^{11}$ Там само, с. 110

${ }^{12}$ Там само, с. 111.
} 
тесане, грубе, й дуже засмагле, зациганіле, але ж очі добрі, ніс трохи закоцюрблений, вуса пухнаті, - молодиці кажуть, що я чоловік не злий, мужньої вроди, не красень, звичайно, але гожий. Ото тільки лисина... Так то - розум ${ }^{13}$.

Ще одним надзвичайно важливим моментом у специфічно мушкетиківському баченні характерництва як явища, що складалося на межі фольклорного осмислення образу козака як захисника рідної землі та філософського аспекту народного світогляду, є ще одне антиномічне поєднання. Розмірковуючи над складовими людського щастя, Семен Білокобилка доходить висновку: „[...] найперше, воно в любові. До матері, до сусідів, до рідної землі. Я часом гірко ненавиджу, але ще дужче люблю. Це і є життя”, адже як багато людей живе, ,[...] жодного разу не скуштувавши свіжого плоду ...свіжого слова, свіжої любові, запеклої ярості і злоби"14.

Отже, характерник у Юрія Мушкетика постає як людина, максимально наповнена дарами життя, серед яких любові ніколи не відчути без ненависті. У цьому образ Білокобилки багато в чому стає суголосним філософській іпостасі мандрівного філософа Дорофія Ружі з його ж роману Яса (1970), адже бачення свого призначення і місця у світі Семен формулює так:

Славлю Бога, що бачу світ, що маю дужі руки та ноги, душу не забруднену кіптявою, в яку світить сонце. Я не зганьбив себе й не зганьблю надалі, не зрадив товариства, не зраджу й нині, я прожив, як міг, і хоч зазнав неймовірних злигоднів, зазнав і щастя, нехай і солоно, але щастя бачити сонце, гарних жінок, мчати на коні проти вітру, рубати ворогів, пити оковиту і їсти пасхальні яйця. Я все це спізнав, і шкодувати мені ні за чим ${ }^{15}$.

Козацтво в першовитоках своїх формувалося не тільки як військове об'єднання, а і як культурно-історичний феномен.

Він тісно пов'язаний з аграрно-магічною обрядністю, з ії обов'язковим перевтіленням людини в іншу істоту, із спрямуванням на якомога тісніший контакт з силами природи. Як відомо, уміння козака-характерника обертатися тваринами в українській демонології не тільки не засуджувалося, навпаки, було складовою його героїчної сутності ${ }^{16}$.

В українських легендах та переказах ставлення до вовка не вороже, бо він знищує нечисть. Проте героєм роману Мушкетика є не воїн, а характерник 3 ознаками національного характеру, оборонець свого роду. Тому символом Білокобилки є собака Пундик (одвічний символ бенкету, родового столу) - швидкий, хитрий і розумний. Асоціативний зв'язок з трагічною рокованою долею Семена розгортається в нехитрій історії єдиного на цілий хутір пса, якого не розірвали вовки, бо всіх інших собак заманювала вийти 3 двору на розтерзання вовчої зграї підступна вовчиця.

${ }^{13}$ Там само, с. 115

${ }^{14}$ Там само, с. 71.

15 Там само, с. 70 .

${ }^{16}$ Л. 3 а л і з н я к, Українська міфологія: образ воїна-звіра, [в:] „Пам’ятки України” 1991, № 5, c. 40-43. 
Виділяючи ряд важливих ознак для потрактування феномену характерництва, В. Нарівська називає й такі:

- характерник, як і герой міфу, втілює родове начало, в тому числі й родову свідомість, на відміну від маргінальної особистості, де ця нерозривна єдність порушується, причому незалежно від того, іде маргінальна особистість на розрив 3 родовим началом чи прагне до повернення в його лоно. Цей процес цілком є однією з форм побутування національного характеру;

- характерник, як і герой міфу, завжди має дублера ${ }^{17}$.

Специфічною ознакою художньої сутності характерника в романі Юрія Мушкетика Погоня є той факт, що обидві виділені ознаки поєднуються, причому дублерство замінюється виведенням цілковитого антиподу Семена Білокобилки, Пива, окрім того, він постає не просто як маргінальна особистість, а уособлює одне з найболючіших і найстрашніших явищ національного буття - зрадництво. Першим кроком до зради стає підступне зведення сестри Василини, що відбувається в той час, коли молодий Білокобилка трохи не молився на старшого Пива. Колись потрібні один одному для цілковитого усталення внутрішнього трибу душі, Білокобилка і Пиво стають лютими ворогами. I все ж навіть у спалахах найзапеклішої люті Семен продовжує роздуми про причину такого страшного перевертання власної природи зрадника. Докорінна відмінність героїв полягає в тому, що Білокобилка стверджується в житті як людина, що діє з серця, Пиво розтрачує життєву снагу у хвилинних примхах. Колишнє „доганяй”, „тримайся” старшого товариша змінюється на пекельне „замордую”, „утоплю” відтоді, як відбувається перехід до ворожого стану. Філософська споглядальність, специфічність якої для мушкетиківського героя полягає в її безпосередній наповненості реаліями і конкретикою життя, найповніше розгортається саме у спробах осягти і зрозуміти страшні переступи Пива як трагедію всієї України.

Цілком слушно звучить висновок Л. Ромащенко щодо головної настанови роману Погоня:

Пригоди Семена Білокобилки та його побратимів органічно вписуються в історичну атмосферу. Незважаючи на те, що сюжетно роман пов'язаний з добою кінця XVII - поч. VIII століть, він звернений до сьогодення, головний герой роману мислить категоріями нашого часу. Таким чином, автор роману намагається розв'язати вічні й завжди актуальні проблеми, екзистенційні за своєю природою: добро і зло, любов і ненависть, правда і олжа, свобода і рабство, сенс життя і смерті ${ }^{18}$.

Подаючи образ характерника, Юрій Мушкетик багато в чому порушує усталену традицію розглядати цей національний тип не як певний характер, а як окрему сутність, не залежну від соціальних обставин. Автор розкриває

${ }^{17}$ В. Н а р і в с ь к а, зазнач. праця.

18 Л. Р о м а щ е н к о, Жанрово-стильовий розвиток сучасної украӥнської прози: основні напрями художнього руху, Черкаси 2003, с. 386. 
глибинний ліризм героя, подаючи своєрідну історію перетворення Семена на характерника. Білокобилка весь час перебуває на межі можливого і неможливого. Не раз і не два зустрічаючись зі смертю віч-на-віч, герой знаходить у собі сили знову і знову повертатися до життя.

У той же час необхідно зазначити, що тема руйнації проходить наскрізно через увесь роман. У запустіння приходять колись багаті і прекрасні українські села, через які проїздить герой, те ж саме відбувається і з його рідним обійстям. Семен своєрідно утримує в собі кінці і початки, і в цьому авторське свосрідне трактування образу характерника, який не протистоїть козацтву, а поступово відходить від нього, маючи потенційну можливість створити нове життя, що, однак, так і залишається нереалізованим у романі.

Уведення зменшувально-пестливого суфікса наповнює звучання прізвища героя своєрідною ніжністю і дитинною вразливістю. Головна особливість художнього вирішення образу характерника в Юрія Мушкетика полягає в тому, що автор, удаючись до улюбленого прийому контрастного зображення, поєднує в ньому антитетичні начала, коли життєві обставини фактично змушують Семена йти проти свого власного єства, і характерництво постає як глибоко трагічне виявлення внутрішніх борінь людської душі. 3 іншого боку, прізвище героя містить зв'язок саме 3 народними уявленнями про надприродні можливості людини, володіння якими є невід'ємною ознакою характерника.

Одним із аспектів, пов'язаних із феноменом характерництва, для Юрія Мушкетика стала можливість якомога повніше передати особливості народної демонології, у якій досить своєрідно розкриваються погляди на темний бік буття людини. Інфернальні сили в романі постають такою ж невід'ємною складовою життя українського села, як і всі інші природні стихії. Серед їх світу панує така ж ієрархічна структура, як і серед людей. Єдиний поділ - це розділеність дня, що належить людським створінням, та ночі, яка віддана бісовому родові. Особлива здатність характерника в цьому аспекті зображення полягає в тому, що він однаково вільно бачить обидва світи, вбирає багато чого від кожного з них, не будучи приналежним жодному. Представники потойбічного світу, будучи нічною, тіньовою стороною буття, скоріше увиразнюють усе, що може бути світлим і справжнім людським началом, бо в основі своій існують за тими ж принципами. 